\title{
PRIVATE PROSECUTIONS IN NEW ZEALAND - A PUBLIC CONCERN?
}

\author{
Anna Louise Prestidge*
}

\begin{abstract}
This article evaluates whether private prosecutions remain a safe and useful mechanism in the modern New Zealand criminal justice system. Private prosecutions are an important constitutional safeguard against state inertia, incompetence and bias and recent legislative reforms have strengthened the judiciary's ability to ensure this mechanism is not misused. Despite this, concerns remain. This article provides an overview of private prosecutions and justification for their continued existence, outlines the current procedure for those prosecutions and explores remaining concerns with this mechanism. Ultimately, while the status quo of private prosecutions remains adequate, a greater alignment of the theoretical and practical purposes of private prosecutions would be beneficial. Further normalisation and commercialisation of private prosecutions is undesirable and the effectiveness of these prosecutions as a "safeguard" is questionable given the considerable financial and investigative burdens faced by applicants.
\end{abstract}

\section{INTRODUCTION}

It is undeniable that New Zealand's criminal justice system is dramatically different from its early Anglo-Saxon roots. ${ }^{1}$ However, one similarity that remains is the ability of a private person to bring criminal proceedings against another. Private prosecutions are often regarded as an "important safeguard" for New Zealand citizens. ${ }^{2}$ These prosecutions are rare in the modern criminal environment and consequently, little academic attention has been paid to them. Yet, where the use of private prosecutions has been considered, concerns have been raised. ${ }^{3}$

* Submitted for the LLB (Honours) Degree, Faculty of Law, Victoria University of Wellington, 2018. I would like to thank my supervisor, Tony Smith and my family and friends for their invaluable support and guidance.

1 Philip C Stenning The Modern Prosecution Process in New Zealand (Victoria University Press, Wellington, 2008) at 25 .

2 Law Commission Criminal Prosecution: A Discussion Paper (NZLC PP28, 1997) at [436].

3 See for example Bill Hodge "Private Prosecutions: Access to Justice" [1998] NZLJ 145; and Law Commission Criminal Prosecution (NZLC R66, 2000). 
Now, nearly 20 years after the last comprehensive review of private prosecutions in New Zealand, ${ }^{4}$ this article returns to the subject and evaluates whether private prosecutions remain a safe and useful addition to the law in light of recent legislative changes. First, this article provides a descriptive overview of these proceedings, with a definition, brief history and justification for their continued existence. It then outlines the current procedure for private prosecutions and, in doing so, describes how the Criminal Procedure Act 2011 (CPA) brought greater oversight to private prosecutions. Finally, this article highlights remaining concerns with this mechanism, cautioning against further commercialisation and normalisation, and questioning the effectiveness of this mechanism as a "safeguard" given the considerable financial and investigative burdens faced by applicants.

\section{PRIVATE PROSECUTIONS IN THE CRIMINAL LAW}

\section{A Definition}

Private prosecutions are prosecutions commenced and managed by individuals or entities other than the state. This article adopts the CPA definition of a private prosecution, being: ${ }^{5}$

... a proceeding against a defendant in respect of an offence that is not-

(a) a public prosecution; or

(b) a proceeding in respect of an offence commenced by or on behalf of a local authority, or other statutory public body or board[.]

Public prosecutions, by contrast, are proceedings commenced by or on behalf of the Crown, including Crown entities. ${ }^{6}$ Despite this distinction, private prosecutors may still be public in nature or function. Private prosecutors include local government agencies and public boards and bodies. Other classes of private prosecutors include private agencies that enforce particular enactments, organisations interested in enforcing particular statutes, individuals or commercial enterprises acting for their own cause and commercial businesses that undertake private prosecutions on behalf of others. $^{7}$

4 Law Commission, above n 3.

5 Section 5.

6 Criminal Procedure Act (CPA), s 5. See Crown Entities Act 2004, s 7 for the meaning of "Crown entity".

7 For more information on classes of private prosecutors see Law Commission, above n 3, at 92-93; and Stephanie Bishop and others (eds) Garrow and Turkington's Criminal Law in New Zealand (looseleaf ed, LexisNexis) at [CPA 5.1]. 


\section{B History}

The history of private prosecutions in the criminal law is defined not by its emergence, but rather its decline. The criminal justice system in medieval England, which forms the foundation for the modern New Zealand system, was founded upon the assumption that the responsibility for preserving peace and bringing offenders to justice was one which belonged to every member of the community. Initially, there was no formal machinery for the prosecution of criminal offences, rather the system relied heavily on the initiative of private citizens. ${ }^{8}$ Grand juries made of ordinary citizens investigated serious crimes and initiated proceedings, presenting their findings and the accused person to a justice of the King's Bench. ${ }^{9}$ However, by the end of the 16th century, the role of the grand jury had gradually evolved from being "self-informed and active" to "static, passive, ignorant", relying on victims and aggrieved citizens to bring evidence to them instead. ${ }^{10}$ This movement was paralleled by the development of rules of evidence, proof of facts and the professionalisation of people involved in these processes. ${ }^{11}$ A disciplined professional police force was established in 1829 and, in part due to the serious decline in the standards of private prosecutions, police gradually acquired the roles of investigator and prosecutor. ${ }^{12}$ The office of the Director of Public Prosecution was created in 1879, although the Director and their staff only intervened in important and difficult prosecutions. It was not until 1985 that a complete system of public prosecution was established in Britain. ${ }^{13}$ Ultimately, Friedman describes a gradual "master-trend" in the history of criminal justice "from private to public, and from lay to professional". ${ }^{14}$

New Zealand adopted many of the key features of the British criminal justice system during the country's colonisation in the early 1840s, including the ability for private citizens to commence a prosecution. ${ }^{15}$ Crown prosecutors were introduced almost from the establishment of British law in New Zealand ${ }^{16}$ and police acted as prosecutors in summary cases first, though by 1864 , police also acted for indictable cases. ${ }^{17}$ As the role of these public prosecutors gradually grew in dominance and

8 Stenning, above n 1 , at 39.

9 Law Commission, above n 2, at [38]-[39].

10 Hodge, above n 3, at 145.

11 At 145; and Law Commission, above n 2, at [22].

12 Law Commission, above n 2, at [44].

13 At [45].

14 Lawrence M Friedman Crime and Punishment in American History (Basic Books, New York, 1993 ) at 174.

15 See Stenning, above n 1, at 60-61 for a description of the key features of the British criminal justice system adopted by New Zealand.

16 Law Commission, above n 2, at [53]-[54].

17 At [50]. 
intensified in expertise, private prosecutors, in turn, became less common. ${ }^{18}$ Nowadays most prosecutions in New Zealand are public in nature, instigated by Crown Solicitors, the police and relevant Ministries and Crown agencies ${ }^{19}$ such as WorkSafe, who enforce the Health and Safety at Work Act 2015 ("HSWA"). ${ }^{20}$ Private prosecutions, by contrast, are rare in comparison.

\section{Purposes}

Private prosecutions fulfil several important purposes in the modern era. Prosecuting criminal offenders is a central function of the state and private prosecutions play a fundamental constitutional role in protecting this state power against misuse, or more commonly omitted use. By allowing private individuals to bring their own criminal proceedings, the public is safeguarded against inertia, incompetence or biased decision-making by the state. ${ }^{21}$ Given this role, it is unsurprising that private prosecutions often concern political or public figures. ${ }^{22}$ Providing the public with this opportunity to be heard, in turn protects the integrity and community trust of the judicial system and Crown. ${ }^{23}$

Further, it is well-known that the abilities of the state to investigate and prosecute are not limitless. Financial restraints heavily confine and dictate the state's prosecutorial decisions and interpretation of policies and principles. ${ }^{24}$ Consequently, low-level offences are often downgraded and deprioritised. ${ }^{25}$ In particular, offences that do not result in harm, such as inchoate offences or criminal nuisance where there is no injury, are often not prosecuted. ${ }^{26}$ Private prosecutions therefore supplement state prosecutorial deficiencies that exist as a result of economic limitations, as well as those that exist through state negligence and abuse. ${ }^{27}$

18 For a more complete overview of the beginnings of New Zealand's prosecutorial system see Stenning, above n 1, at 23-99; and Law Commission, above n 2, at [37]-[55].

19 Julia Tolmie and Warren Brookbanks Criminal Justice in New Zealand (LexisNexis, Wellington, 2007) at [8.3.1].

20 See Crown Entities Act, sch 1; and Health and Safety at Work Act 2015 for more information.

21 Law Commission, above n 2, at [436], as cited in Taka v District Court at Auckland [2015] NZHC 972 at [12]. See also the original dicta of Lord Wilberforce in Gouriet v Union of Post Office Workers [1978] AC $435(\mathrm{HL})$ at 498.

22 See for example Bright v Key [2009] NZAR 532 (HC); and "Mallard pleads guilty to fighting, says sorry to consultant" New Zealand Herald (online ed, Auckland, 18 December 2007).

23 Creeggan v New Zealand Defence Force DC Wellington CRI 2014-085-007231, 18 July 2014 at [48].

24 Crown Law Office Solicitor-General's Prosecution Guidelines (1 July 2013) at [5.7].

25 Hodge, above n 3, at 147.

26 Fran Wright "Criminal Nuisance: Getting Back to Basics" (2005) 21 NZULR 665.

27 Law Commission, above n 3, at [260], referring to the submission from Private Prosecutions Ltd. 
In consequentialist theory, prosecution and punishment operate as a form of behaviour modification by deterring citizens from engaging in harmful activities. ${ }^{28}$ Selective prosecuting by the state reduces the risk of being prosecuted, creating a disincentive for complying with the law. Submissions in favour of lifting the state monopoly to prosecute offences under the Health and Safety at Work Amendment Act 2002 implied it was common knowledge that the Occupational Health and Safety Management Service responded to only the worst cases: "employers know that unless they kill their workers, their prosecution risk is minimal". ${ }^{29}$ Agencies play an important role in prosecuting low-level and inchoate offences, stepping in and stopping dangerous conduct before harm occurs. As Dabee emphasises: "the use of private prosecutions to prosecute minor violations may prevent the 'normalisation' of ignoring safety regulations, and prevent a more serious accident from happening." 30

Private prosecutions further deter criminal behaviour and fulfil the state's economic limitations by enabling more people to prosecute. For example, commercial competitors have the greatest interest in ensuring competing businesses do not get unfair price advantages by not adhering to legal standards. They are therefore willing to use the full extent of their commercial resources to ensure that any deviation from legal obligations is prosecuted. ${ }^{31}$ Further, private prosecutions enable groups with specific interests, such as unions and organisations to bring proceedings. These groups may be more aware of committed offences as victims may be more willing to report violations to unions and organisations rather than to regulators or the police. ${ }^{32}$

The impact of lifting the Crown's monopoly over health and safety offences in the workplace highlights the importance of private prosecutions. Private prosecutions were introduced to the regime in 2002 in part due to suspicions that worthy cases were not being prosecuted. ${ }^{33}$ The New Zealand Council of Trade Unions' submission on the Health and Safety in Employment Amendment Bill criticised the regime as being unable to prevent workplace accidents: ${ }^{34}$

28 AP Simester and WJ Brookbanks Principles of Criminal Law (4th ed, Brookers, Wellington, 2012) at 17.

29 Robyn Houltain "Submission to the Transport and Industrial Relations Select Committee on the Health and Safety in Employment Act Amendment Bill" at 2, as cited in Natalie K Fraser "Smoke and Mirrors: The Introduction of Private Prosecutions under s 54A of the Health and Safety in Employment Amendment Act 2002" (2003) 9 Auckland U L Rev at 1246.

30 Nadia Dabee "Private prosecutions and workplace health and safety" [2015] NZLJ 371 at 372.

31 Richard Johnstone and Michael Tooma Work Health and Safety Regulation in Australia: The Model Act, (Federation Press, Sydney, 2012) at 193.

32 Dabee, above n 30, at 372.

33 Hazel Armstrong and Robert Brier "Enforcing the HSE Act" [2003] NZLJ 259.

34 New Zealand Council of Trade Unions "Submission to the Transport and Industrial Relations Select Committee on Health and Safety on the Employment Act Amendment Bill 2002", as cited in Fraser, above n 29 , at 1236. 
Enforcement of the Act by the Department of Labour has been "soft", providing further encouragement to employers who decide to "take the risk" that they won't be prosecuted for breaches of the Act, even in fatal cases where prosecution would appear to be warranted.

Similarly, statistics released by the Minister of Labour in 2001 found an average of only one in 1,000 non-compliant workplace behaviours were being prosecuted. ${ }^{35}$ Since lifting the monopoly, numerous private prosecutions have been successful. In 2015, two private prosecutions were brought by the Council of Trade Unions against forestry companies for the death of workers Charles Finlay and Eramiha Pairama. In both cases, WorkSafe had investigated the incidents and decided not to prosecute. Despite this, both private prosecutions were won "with incredible ease". ${ }^{36}$ Further in 2014 , the New Zealand Defence Force pleaded guilty to failing to take practical steps to ensure the safety of its employees following a helicopter crash that killed four crew members. Justice Hastings concluded his judgment by emphasising to Sergeant Creeggan, the private prosecutor and sole survivor of the crash: ${ }^{37}$

... you are proof that one person can make a difference. By dint of your tenacity and resolve, you have managed to create a silver lining from an unimaginable tragedy that has seared itself into the nation's psyche. You have demonstrated what the amendment legislation permitting private prosecutions set out to achieve. The New Zealand Defence Force is a better employer and the honour of the Crown has gone some way to being restored as a result of your actions.

Commentator Bill Hodge additionally argues that private prosecutions provide a "pragmatic window of opportunity for the public to participate in a fundamental state service". ${ }^{38}$ Jurors aside, New Zealanders are provided with little democratic opportunity to participate in the operations of the criminal justice system. Appointments for key positions, such as the judiciary and the Crown Solicitors, are neither transparent nor well-known. ${ }^{39}$ Being able to involve the public and show justice and due process operating in this opaque sector would help to restore faith and confidence in the

35 Department of Labour Discussion Paper on Review of the Health and Safety in Employment Act 1992 (December 2001) at 17

36 (25 August 2015) 708 NZPD 6089. For further information see Radio New Zealand "WorkSafe declines, private prosecution wins" (3 August 2015) <www.rnz.co.nz>; and Mike Mather "Puketi Logging sentenced over death of Eramiha Pairama" Stuff (online ed, Wellington, 1 October 2015).

37 Creeggan, above n 23, at [48].

38 Hodge, above n 3, at 146.

39 See Crown Law Office Judicial Protocol (April 2014); and Crown Law Office Crown Solicitors: Terms of Office (May 2017) at [6] for more information on these appointment processes. 
criminal justice system. ${ }^{40}$ Private prosecutions, arguably even where unsuccessful, allow for public accountability and independent scrutiny of the Crown. ${ }^{41}$

Finally, private prosecutions are often argued as having particular importance for victims of crime. The ability to instigate prosecutions allows those impacted by criminal activity to express their interests and liberty into the law and implement the administration of justice. ${ }^{42}$ As Hodge expressed, in reflecting on his personal experiences with legal redress: ${ }^{43}$

... the opportunity of private prosecution, and the availability in theory of that opportunity, itself enabled

a therapeutic consideration of the issues. Had that window been shut, then bitterness and frustration would

have intensified, and emotional closure not been possible.

Private prosecutions can have a cathartic effect for victims even where unsuccessful. Victims are provided with the security of knowing that their story and concerns were properly and unbiasedly reviewed. ${ }^{44}$ It also provides aggrieved citizens with recognition of their right to be heard and to natural justice. $^{45}$

This cathartic or intended cathartic effect has played out in New Zealand media for several high profile private prosecutions in recent years. ${ }^{46}$ This purpose could be said to be especially important in modern New Zealand given the statutory bar to civil personal injury claims.

However, it should not be argued that private prosecutions have a purpose of providing individual justice for victims. Rather, any cathartic effect for victims and families should be perceived as a bonus. In modern criminal theory, offences are conceptualised as inflicting harm upon society as a whole rather than individual victims. ${ }^{47}$ This is translated into state policy by commencing prosecutions only

40 Hodge, above n 3, at 146.

41 Creeggan v New Zealand Defence Force [2014] DCR 244 (DC) at [27].

42 Tyrone Kirchengast The Victim in Criminal Law and Justice (Palgrave Macmillan, London, 2006) at 192.

43 Hodge, above n 3, at 147.

44 See Hannah Bartlett "Driver found 'not guilty' in ex-cop's private prosecution" Stuff (online ed, Wellington, 25 May 2018).

45 Prescott v District Court at North Shore [2017] NZHC 2828, [2018] NZAR 307 at [48].

46 See for example Parker v Rangitonga [2017] NZDC 7581, as cited in Tony Wall "Man who attacked Tauranga woman jailed after private prosecution" Stuff (online ed, Wellington, 10 April 2017).

47 Tolmie and Brookbanks, above n 19, at [8.2.1]. 
where the public interest requires. ${ }^{48}$ The impersonal nature of the modern criminal justice system is designed: 49

... to ensure that the punishment [judges] impose in the name of the community is itself a civilised

reaction, determined not on impulse or emotion but in terms of justice and deliberation.

It lessens the fire for private vendettas and vengeance, and removes the "personal, often emotional, involvement of individual victims" from the criminal justice system which can "generate very particularised interests in the outcome of cases; and these individual interests may have little to do with the public interest". ${ }^{50}$ However, recently victims have been granted a greater role and emphasis in the criminal law. This "repersonalising" of the criminal justice system risks turning back the clock to early systems once overtaken by historical evolution. ${ }^{51}$ Therefore, justifying private prosecutions as providing individual justice undermines the intentions of the criminal justice system. Further, it is questionable whether the involvement of the victim in the criminal justice process actually helps victims recover or whether they are instead revictimised through the process. ${ }^{52}$ It has been suggested that direct assistance may be more beneficial for victims than a sense of ownership in the criminal justice process. 53

In overseas jurisdictions, arguments have been advanced as to whether private prosecutions remain a valuable right in light of other safeguards and mechanisms. ${ }^{54}$ For example, England and Wales have the Crown Prosecution Service, an independent prosecuting authority that prosecutes cases following investigations by the police and other organisations. ${ }^{55}$ As part of this service, victims of crime have a special right of review for decisions not to prosecute. ${ }^{56}$ In contrast, New Zealand has no special victim right of review in the Victims' Rights Act 2002. Nor are the executive's decisions not to prosecute generally susceptible to judicial review. To ensure the judiciary does not overstep constitutional boundaries and engage in high-content, discretionary questions, the intensity of the

48 See "The Public Interest Test" in Solicitor-General's Prosecution Guidelines, above n 24, at 8-10.

$49 R$ v Puru [1984] 1 NZLR 248 (CA) at 249.

50 JL Hagan Victims Before the Law: The Organizational Domination of Criminal Law (Butterworths, Oxford, 1983) at 3, as cited in Tolmie and Brookbanks, above n 19, at [8.2.1], n 14.

51 Sian Elias "Blameless Babes" (2009) 40 VUWLR 581 at 584.

52 At 584 .

53 At 584

54 See for example Jones $v$ Whalley [2006] UKHL 41, [2007] 1 AC 63 at [9] and [16].

55 "About CPS" The Crown Prosecution Service <www.cps.gov.uk>.

56 Ministry of Justice Code of Practice for Victims of Crime (October 2015) at 89. This encompasses the victim's right to review a decision not to prosecute as contained in the European Union Directive 2012/29 establishing minimum standards on the rights, support and protection of victims of crime. 
review and the availability of relief is constrained ${ }^{57}$ Review and relief is likely to be obtained only where there has been a failure to exercise discretion, such as by the adoption of a general policy not to prosecute certain offences or in "exceptional cases". ${ }^{58}$ Other safeguards for decisions not to prosecute, such as the responsibility of relevant ministers to Parliament or commissions of inquiry, do not usually result in convictions. Nor do they arguably provide the same deterrent effect, accountability and public assurance that such offences will not be repeated as private prosecutions do. ${ }^{59}$ Furthermore, even in the United Kingdom there are still cases that fall out of their review schemes. ${ }^{60}$ Therefore private prosecutions continue to be a fundamental safeguard in modern legal systems.

\section{CURRENT PROCEDURE}

\section{A Scope}

The modern authority for private prosecutions is contained in ss 10 and 15 of the CPA. These sections allow "any person" to commence and then conduct a prosecution. ${ }^{61}$ Private prosecutions can be commenced for any criminal offence unless specified otherwise. Under HSWA, private prosecutions may be commenced only where the regulator has not taken and does not intend to take enforcement and prosecution action in respect of the circumstances in question, ${ }^{62}$ or where the prosecutor gains the leave of the court through the CPA. ${ }^{63}$ In both situations, the person must have received a notification from the regulator that enforcement or prosecution has not and will not be taken. ${ }^{64}$ Some criminal offences explicitly exclude the ability to bring a private prosecution without the consent of the Attorney-General or, as often occurs, the Solicitor-General. ${ }^{65}$ Other offences

57 Osborne v Worksafe New Zealand [2017] NZCA 11, [2017] 2 NZLR 513 at [34].

58 At [35]. For more information on judicial review of decisions not to prosecute see Graham Taylor Judicial Review A New Zealand Perspective (4th ed, LexisNexis, Wellington, 2018) at [2.36].

59 Creeggan, above $\mathrm{n} 41$, at [31].

60 See for example $R$ (on the application of AC) v Director of Public Prosecutions [2018] EWCA Civ 2092, [2019] 1 WLR 917.

61 However, where matters proceed to a jury trial only a lawyer may conduct the case as provided by the CPA s 10(3).

62 Section 144(1).

63 Section $144(3)(a)$

64 Health and Safety at Work Act 2015, s 144(1)(c) and (3)(b) [HSWA].

65 By virtue of Constitution Act 1986, s 9A. Offences include Crimes Act 1961, ss 124(5) and 124A(5); and Films, Videos and Publications Classification Act 1993, s 144. 
sometimes require the Attorney-General's consent or leave of the court prior to commencing any criminal proceeding more generally. ${ }^{66}$

The ability to commence a private prosecution is also time restricted. Section 25 of the CPA specifies time periods for when category 1, 2 and 3 offences may be brought. Charging documents in respect of category 4 offences can be brought at any time. ${ }^{67}$ Section 148 of HSWA similarly sets out limitation periods for offences under that Act. ${ }^{68}$

\section{B Commencing Private Prosecutions}

The process for commencing a private prosecution is outlined in s 26 of the CPA. The Registrar has the power to either accept a charging document for a private prosecution for filing or refer the matter to a District Court Judge. ${ }^{69}$ While there is no guidance as to when registrars should refer files to judges, commentary suggests registrars routinely direct files involving lay litigants to judges but accept documents from local authorities or public boards and bodies without referral. ${ }^{70}$ Where a judge is making the decision, the judge must direct further evidence to be filed. ${ }^{71}$ Decisions made by either the judge or registrar under s 26 are susceptible to judicial review but not appeal. ${ }^{72}$ Where the charging documents are accepted, summons are issued on behalf of the prosecutor by either the judge or registrar. ${ }^{73}$

Section 26(3) outlines the two grounds on which judges may decline the charging document: where evidence is insufficient to justify a trial or where the prosecution is otherwise an abuse of process. Precedent regarding s 147 of the CPA, which gives judges discretionary power to terminate proceedings, and its previous equivalent, s 347 of the Crimes Act, assists in interpreting the threshold for these grounds. ${ }^{74}$ However case law indicates that since the s 26 assessment operates as a check at

66 For a list of these offences see Crown Law Office Statutory Offences Requiring the Consent of the AttorneyGeneral (1 July 2013).

67 CPA, s 25(1).

68 See also s 149 for exceptions to this limitation period.

69 CPA, s 26(1).

70 Bishop and others, above $\mathrm{n}$ 7, at [26.1].

71 CPA, s 26(1)(b) and s 26(2).

72 Mitchell v Tyson [2016] NZHC 2210, [2016] NZAR 1545 at [37]-[39]; and Mitchell v Porirua District Court [2017] NZHC 1331, [2017] NZAR 1077 at [22]. See also Taylor, above n 58, at [2.42].

73 CPA, s 33.

74 Walters v Chow DC Wellington CRI-2013-085-009988, 31 October 2013 at [9]; and Dixon-McIver v Weston DC Lower Hutt BC201366990, 19 November 2013 at [11]. 
the beginning of the prosecution process, it is unlikely to be applied with the same rigour as s 147 would have. ${ }^{75}$

Evidence is insufficient where, if accepted by the factfinder, it does not prove the essential elements of the charge beyond reasonable doubt. This respects the differing roles of the judge and jury, ${ }^{76}$ ensuring that the judge only comes to a conclusion of insufficiency where the Crown's evidence, taken at its highest, is such that a jury properly directed could not properly convict of it. ${ }^{77}$ Insufficiency also considers the need to access the courts; ${ }^{78}$ evidence may be found to be insufficient to justify where the trial serves no useful purpose or results only in nominal punishment. ${ }^{79}$

Abuse of process concerns situations that would preclude a fair trial or "tarnish the Court's own integrity or offend the Court's sense of justice and propriety." ${ }^{80}$ This includes where no useful purpose would be served by the continuation of the proceedings, where the holding of a trial would be unreasonably burdensome on the defendant, where the prosecution has acted in bad faith or from improper motives or where the prosecution's conduct has a prejudicial impact on the defendant. ${ }^{81}$ Therefore, courts cannot dismiss proceedings merely as a method of disciplining the prosecution or because, in the court's opinion, the proceedings should not have been brought. ${ }^{82}$ Where the prosecution is sought by leave of the court under HSWA, the judge must also take into account consistency with the purpose of the Act and whether it is in the public interest. ${ }^{83}$

The judicial oversight given by s 26 for commencing private prosecutions is new. Prior to the CPA's enactment, private prosecutions could be instigated merely by laying an information for a summary offence ${ }^{84}$ or by filing an indictment form for an indictable offence. ${ }^{85}$ Leave from the court

75 Goodman Fielder New Zealand Ltd v District Court at Porirua [2019] NZHC 599.

$76 R v \operatorname{Kim}$ [2010] NZCA 106, [2010] BCL 310 at [5].

$77 R v$ Galbraith [1981] I WLR 1039 (Crim App) at 1041, as cited in Parris v Attorney General [2004] 1 NZLR $519(\mathrm{CA})$ at $[8]$.

78 Spratt v Savea DC Christchurch CRI-2014-009-001492, 29 April 2014 at [21].

79 Walters, above $\mathrm{n} 74$, at [14].

80 Fox v Attorney-General [2002] 3 NZLR 62 (CA) at [37].

81 Spratt, above n 78, at [18].

82 At [18].

83 HSWA, s 144(5)(b).

84 Summary Proceedings Act 1957, s 13.

85 Crimes Act, s 345(2). 
was not required, however District Court judges, justices, community magistrates and registrars had discretion not to issue summons and warrants of arrest. ${ }^{86}$

Section 26 was a welcomed response to calls for greater judicial oversight of private prosecutions. ${ }^{87}$ It is well acknowledged that the availability of private prosecutions in any criminal justice system risks improper and malicious prosecutions at the peril of a person's liberty. ${ }^{88} \mathrm{New}$ Zealand history shows that numerous private prosecutions sought to abuse this mechanism. ${ }^{89}$ Section 26 was introduced as "a sifting process designed to protect the proposed defendant from an unnecessary or wrong prosecution".90

While s 26 is silent on the hearing rights of prospective defendants, courts have taken a discretionary approach. In Wang v District Court at North Shore (No 2) Woolford J suggested that "the Court undoubtedly has a residual discretion to hear a proposed defendant if it is felt necessary for the purpose of reaching a decision". ${ }^{91}$ Similarly, Brewer J in Taka v District Court at Auckland held that there was no obligation as such to seek the views of the proposed defendant but rather it came down to the proper exercise of judicial discretion. ${ }^{92}$ Discretion would be best exercised where the private prosecutor has a personal interest in the prosecution and the "subjective nature of his approach to the case is evident on the materials ... filed". ${ }^{93}$ This discretionary approach has been supported by other judges ${ }^{94}$ and, for reasons that will be discussed later, is supported by this article.

\section{Obligations on Private Prosecutors}

In the past, commentators have raised concerns that public and private prosecutors were subject to different obligations. For example, in the Law Commission's report, it was pointed out that private prosecutors were not obliged to disclose relevant information and the Official Information Act 1982

86 Summary Proceedings Act, s 19, as discussed in Burchell v Auckland District Court [2012] NZHC 3413, [2013] NZAR 219 at [22]-[24].

87 Law Commission, above n 2, at [445]; and New Zealand Police Association "Submission to the Justice and Electoral Committee on the Criminal Procedure (Reform and Modernisation) Bill" at [6].

88 Law Commission, above n 2, at [439].

89 See for example $R v$ Holden HC Auckland T981504, 4 September 1998.

90 Taka, above n 21, at [45].

91 Wang v District Court at North Shore (No 2) [2014] NZHC 2756, [2014] NZAR 1428 at [57].

92 Taka, above n 21, at [44]-[45].

93 At [46].

94 Jan-Marie Doogue "Five Topics Relevant to Criminal Procedure" At the Bar (New Zealand, December 2015) at 9 . 
and Privacy Act 2003 did not necessarily apply to them. ${ }^{95}$ While the application of these Acts is still dependent on the type of private prosecution being brought, disclosure obligations are now uniform across all prosecutors. The Criminal Disclosure Act 2008 explicitly applies to private prosecutors. ${ }^{96}$ Other relevant criminal procedure statutes similarly apply to both types of prosecutors, such as the Crimes Act ${ }^{97}$ and Costs in Criminal Cases Act $1967 .{ }^{98}$ Private prosecutors must also abide by the New Zealand Bill of Rights Act 1990. ${ }^{99}$

\section{Safeguards}

Private prosecutions are also subject to a number of inherent safeguards to prevent abusive court behaviour. As discussed above, s 147(1) of the CPA gives judges discretionary power to terminate proceedings before or during the trial in favour of the defendant. ${ }^{100}$ Grounds for dismissal include where there is insufficient evidence to justify trial or where the prosecution is an abuse of process. ${ }^{101}$ The CPA further grants the Attorney-General the ability to intervene in the process and stay a prosecution, recognising the office's ultimate constitutional responsibility for prosecutions. ${ }^{102}$ In addition, the District and High Court have jurisdiction to stay criminal proceedings. ${ }^{103}$ Where private prosecutions have been improperly commenced, defendants can seek remedies through the tort of malicious prosecution, though this threshold is not easily met. ${ }^{104}$ Commentators also point to the cost of investigating, preparing and bringing proceedings as a significant deterrent to misusing private prosecutions. ${ }^{105}$ However, as will be discussed later in this article the impact of costs is a concern to the availability of private prosecutions.

95 Law Commission, above n 3, at [258].

96 Section 6(1) definition of "prosecutor".

97 Crimes Act, s 2.

98 Law Commission, above n 2, at [440].

99 Section 3(b). See for example Taylor v Sand HC Auckland T 28/93, 18 December 1995 at 9.

100 See for example Rensen v A (Ruling) DC Hamilton CRI-2014-068-000138, 18 November 2014.

101 Section 147(4)(a).

102 Section 176

103 For the High Court, see High Court Rules 2016, r 15.1; and Christopher Corry and others (eds) Sim's Court Practice (online ed, LexisNexis, January 2018) at [HCR 15.1]. For the District Court, see Moevao $v$ Department of Labour [1980] 1 NZLR 464 (CA). See also Ratima v Tauranga District Court [2012] NZHC 1306 for judicial review of a District Court stay in relation to a private prosecution.

104 Stephen Todd and others (eds) The Law of Torts in New Zealand (7th ed, Thomas Reuters, Wellington, 2016) at 1036. See ch 18.2 "Malicious Prosecution" for more information.

105 Law Commission, above n 2, at [440]; and Hodge, above n 3, at 147-148. 
These safeguards are very similar to those which existed prior to the CPA. Under the Crimes Act, courts similarly retained discretionary powers to quash counts and stay proceedings either before or during trial for want of evidence or where an injustice has been or is likely to be done to the accused. ${ }^{106}$ The Attorney-General again also possessed jurisdiction to stay proceedings. ${ }^{107}$ From 2006-2011, the Solicitor-General issued 57 stays of proceedings for improperly pursued private prosecutions by individuals. ${ }^{108}$

The effect of s 26 has been to reduce the reliance on safeguards to remove improper and inappropriate private prosecutions. It allows for earlier dismissals of such proceedings, streamlining the approach and reducing the burden on defendants by decreasing the need to apply for a stay or dismissal of the prosecution.

\section{AREAS OF CONCERN}

While recent legislative reforms have helped ensure that private prosecutions are not vexatious or unmeritorious, concerns regarding their use in New Zealand still remain. First, the mere availability of private prosecution is being used as a vehicle for harm. Second, in this author's opinion, the recent case of Rangitonga $v$ Parker breaches the principle of double jeopardy and uses a private prosecution in a manner outside of the mechanism's intended purposes. ${ }^{109}$ Third, even with the recent reforms, distinctions between private and public prosecutors remain. Such distinctions make further normalisation and commercialisation of private prosecutions a continuing cause for concern. Finally, this article emphasises that for this mechanism to operate as an effective safeguard, victims and aggrieved citizens must have the practical capabilities to instigate proceedings. Significant investigative and financial burdens continue to place this mechanism outside of the reach of those in need.

\section{A Harmful Use}

While s 26 allows the refusal of charging documents, cases show that the mere availability of private prosecutions is being used as a vehicle for harm.

The ability of ordinary citizens to instigate criminal proceedings can be used to coerce, intimidate or threaten others. For example in Thompson v R (Private Prosecution), Chisholm J refused to allow leave to commence a private prosecution in part because the question of whether charges should be laid had become "inextricably interwoven" with a proposal for payment for substantial amounts of

106 Crimes Act, s 345(5) and (6).

107 Summary Proceedings Act, ss 77A and 159. For further information, see summary of "Existing Controls on Private Prosecutions" in Law Commission, above n 2, at [440].

108 John Spencer Review of Public Prosecution Service (Crown Law Office, September 2011) at 71.

109 Parker v Rangitonga [2017] NZDC 7581. 
money to avoid the prosecution. ${ }^{110}$ Similarly, Spencer QC recalls a concerning story of a student in England who, after losing her train ticket, was threatened with a private prosecution unless she paid an "administrative settlement" of GBP 103.90, which included both the "unpaid fare" and a "contribution towards the administrative costs incurred". ${ }^{111}$ As Spencer emphasises, such behaviour is unethical and borders on blackmail. ${ }^{112}$

Further, the knowledge that a person is attempting to commence a private prosecution against another can also be damaging in and of itself. Convictions are designed to be a "public, condemnatory statement about the defendant", 13 and consequently prosecutions carry negative connotations. Private prosecutions have been commenced with the intention to "humiliate, embarrass or otherwise extract revenge". ${ }^{114}$ Others have been attempted alongside media campaigns intended to bring individuals' reputations into disrepute. For example, in National Standards Committee v Denham, a lawyer was suspended from practising law for bringing a private prosecution that was found to be an "abuse of process". ${ }^{115}$ Justice McNaughton summarised the private prosecution in one case as being: 116

... brought for an ulterior motive by the complainant, that is, primarily to destroy his career and reputation and collaterally to damage Kristin school and at the same time to obtain an advantage in pressing the relationship property claim.

As a result of this potential for harm, defamation proceedings have in past been attempted against individuals who have publicly revealed that private prosecutions were being instigated. ${ }^{117}$

At particular risk of vexatious proceedings are those who work in the criminal justice sector. In many cases, private prosecutors have sought to bring proceedings against people involved in their criminal charges, including police officers and judges, after their appeal rights amounted to no

110 Thompson $v R$ (Private Prosecution) [2007] NZAR 722 (HC) at [24]. See also the proposed private prosecution and monetary compensation in Iles $v$ Z [2018] NZHC 1396 at [19]-[25].

111 JR Spencer "Professional private prosecutors and trouble on the trains" [2018] 2 Arch Rev 4 at 4-6.

112 At $4-6$

113 Simester and Brookbanks, above n 28, at 5 .

114 Lincoln v Manning [2018] NZDC 20025, as discussed in Lincoln v New Zealand Law Society [2018] NZHC 3050 at [25]-[27].

115 National Standards Committee v Denham [2017] NZLCDT 10 at [35]

116 Denham v Clague [2015] NZDC 12703 at [59], as cited in National Standards Committee v Denham, above n 115 , at [36].

117 See Duval v Bennison [2015] NZHC 1371. 
avail. ${ }^{118}$ Private prosecutors often instigate proceedings as collateral challenges to negative verdicts against them, ${ }^{119}$ or to express their frustration and disapproval towards the criminal justice system. ${ }^{120}$ The 2017 New Zealand Police Association policy document highlighted the risk individual officers continue to face. ${ }^{121}$ The impact of these cases is substantial to both the emotional and financial wellbeing of these officers and their loved ones. ${ }^{122}$ As the New Zealand Police Association emphasised in their submission on the Criminal Procedure (Reform and Modernisation) Bill: ${ }^{123}$

It is widely known that the costs of initiating such a case by filing documents are practically nil, and that the simple act of so filling itself achieves the objective of "getting back" at Police. There has even been a website devoted to encouraging individuals to do so.

Also at risk are the victims of crime. Private prosecutions can be brought in New Zealand without a victim's consent, ${ }^{124}$ and consequently may be commenced in a manner which causes harm to victims, whether intended or not. Such a concern was noted in New Zealand Private Prosecution Service Ltd v Key, where the Human Rights Review Tribunal found that the proceedings "undoubtedly added to hurt and embarrassment" of the victim and were brought with "apparent indifference" of this impact. ${ }^{125}$ Concerningly, private prosecutions have also been commenced by offenders against their past victims out of vengeance. ${ }^{126}$

Finally, private prosecutions provide just another court mechanism for vexatious litigants to achieve their purpose. When undeserving matters are brought to court, it creates inefficiency, clogs the system with unnecessary cases, wastes public money and jeopardises the repute of the overall process. In the past, several vexatious litigants have brought unsuccessful private prosecutions amongst an array of other judicial applications. ${ }^{127}$ For example, the litigant in Attorney-General v

118 See for example Burchell, above n 86; and Slavich v Heath DC Auckland BC201462470, 14 March 2014. See also Spratt, above n 78 .

119 See for example Slavich, above n 118, at [38].

120 New Zealand Police Association Police and Law \& Order Policies: Towards a Safer New Zealand (2017) at 24.

121 At 24. For a recent private prosecution against a police officer on duty see Lincoln v Manning, above n 114.

122 New Zealand Police Association, above n 120, at 24. See for example the impact of Wallace v Abbott [2003] NZHC 42, (2002) 19 CRNZ 585 as highlighted by Hon Paul Hutchison (23 June 2004) 618 NZPD 13880.

123 New Zealand Police Association, above n 87, at [10]. For information on fees see District Courts and High Courts (Criminal Fees) Regulations 2013, sch 1.

124 Section 15 of the CPA allows "any person" to commence a proceeding.

125 New Zealand Private Prosecution Service Ltd v Key [2015] NZHRRT 48 at [104].

126 See for example van der Platt v District Court at Invercargill [2005] DCR 443 (DC).

127 See for example Attorney-General v Reid [2012] NZHC 2119, [2012] 3 NZLR 630. 
Slavich, had commenced 35 private prosecutions in an attempt to impugn the conduct of those who had been involved in his prosecution at trial. ${ }^{128}$ He was declared vexatious by the High Court. ${ }^{129}$ Similarly, in Honey $v$ Nottingham when declaring Mr Nottingham bankrupt, the High Court stated: 130

Mr Nottingham has a demonstrated history of commencing private prosecutions against individuals in

which he has thus far been entirely unsuccessful. Unquestionably these apparently groundless

prosecutions have wreaked havoc with the lives of those wrongly accused of criminal activity. In my view,

if Mr Nottingham's bankruptcy puts an end to this practice on his part, then that is a public good.

These harms are evidently not solvable by the new oversight that s 26 provides, rather, the harm is achieved even before a decision not to accept the charging documents is made. However, this should not be a reason to forgo the availability of private prosecutions entirely. The discretionary approach under s 26 means that not all defendants will need to be involved in dismissing charging documents, limiting the burden that merely attempting to file charging documents has. Further, some concerning behaviour may be remedied by other parts of the law, such as the offence of blackmail, defamation proceedings and the ability of the courts to declare litigants vexatious. However, the threshold for these will often not be met. Evidently, more needs to be done to protect citizens from the misuse of private prosecutions, particularly for those working in the criminal justice sector.

\section{B Double Jeopardy}

Given that private prosecutions operate alongside the public prosecution system, the availability of this mechanism creates potential double jeopardy concerns. Double jeopardy is a "fundamental" and "all-pervasive" legal principle that requires that no person be tried for the same offence twice. ${ }^{131}$ It recognises the need for finality in criminal proceedings and the power imbalance that exists between the individual and the state. ${ }^{132}$ The principle protects the defendant from continued embarrassment, anxiety and the financial burden of facing multiple prosecutions. Further, by allowing only one attempt at prosecution, it has been theorised to reduce the likelihood of wrong convictions. ${ }^{133}$

Defendants to private prosecutions are safeguarded from breaches of double jeopardy in multiple ways. Charging documents can be rejected at the judges' discretion under s 26 for abuse of process

128 Attorney-General v Slavich [2013] NZHC 627.

129 At [172].

130 Honey $v$ Nottingham [2018] NZHC 2382 at [43]-[44].

131 Martin L Friedland Double Jeopardy (Clarendon Press, Oxford, 1969) at 3.

132 At 3-5; and Green v United States 355 US 184 (1957) at 187-188 per Black J. See also Rangitonga v Parker [2015] NZHC 1772, [2016] 2 NZLR 73 [Rangitonga v Parker (HC)] at [39].

133 Friedland, above n 131, at 3-5; and Green v United States, above n 132, at 187-188 per Black J. See also Rangitonga $v$ Parker (HC), above n 132, at [39]. 
and prosecutions, and as discussed, can be stayed by the Attorney-General or the courts. ${ }^{134}$ Further, defendants can enter a special plea of previous conviction or previous acquittal which prevents defendants from being acquitted or convicted of the same offence or any other offence "arising from the same facts". ${ }^{135}$ The New Zealand Bill of Rights Act additionally recognises the defendant's right not to be tried or punished twice. ${ }^{136}$

In the recent case of Rangitonga $v$ Parker, the Court of Appeal considered whether a private prosecution for a rape charge was barred by double jeopardy. ${ }^{137} \mathrm{Ms} \mathrm{T}$ alleged that Mr Rangitonga violently assaulted her and then raped her after she lost consciousness. Rangitonga initially faced two charges: wounding with intent to cause grievous bodily harm and sexual violation by rape. Prior to trial, the Crown withdrew the wounding charge believing it would enable the jury to focus on the rape charge. However, at trial Rangitonga was acquitted of rape. ${ }^{138}$ Consequently, $\mathrm{T}$ then sought to commence a private prosecution in relation to the wounding charges. The Court of Appeal allowed the prosecution, interpreting the relevant special pleas of previous conviction and previous acquittal to apply where there was a "common punishable act central to both the previous and new charge". ${ }^{139}$ In this case, the central punishing act for both charges was held to be distinct: namely sexual connection without consent for the rape charge and punching and attempted strangulation for the wounding charge. ${ }^{140}$

In his defence, Rangitonga argued the prosecution should be discontinued due to abuse of process. He alleged that his evidence at trial was given in light of his understanding that the wounding charge had been withdrawn. The Court of Appeal dismissed his argument. Rangitonga had no real option but to give evidence at the first trial as Mr T undoubtedly had injuries that needed to be accounted for. ${ }^{141}$ However, the issue remains that Rangitonga believed he was no longer in jeopardy for the wounding conviction. The Court of Appeal expressed this concern in their judgment stating: ${ }^{142}$

Notwithstanding our finding that the special plea is not available to Mr Rangitonga, we have some concerns about the propriety of a private prosecution now proceeding in circumstances where the Crown

134 See Part III(D) above for more information.

135 CPA, ss 46 and 47.

136 Section 26.

137 Rangitonga v Parker [2016] NZCA 166, [2016] NZAR 768 [Rangitonga v Parker (CA No 1)].

138 At [7]-[11].

139 At [41].

140 At [42].

141 Rangitonga v Parker (No 2) [2017] NZCA 47, [2017] NZAR 460 at [8].

142 Rangitonga $v$ Parker (CA No 1), above n 137, at [51]. 
deliberately withdrew the wounding charge prior to his trial for rape. It has not been suggested there was

any indication this charge or any similar charge would or might be re-laid. In these circumstances, $\mathrm{Mr}$

Rangitonga may have had grounds to believe he was no longer in jeopardy on any charge related to his

assault on the complainant.

While not criticising the outcome of this case, it is this author's opinion that this private prosecution does not align with the intended purpose of this mechanism. The lack of conviction following the public prosecution was not due to inertia, incompetence or biased reasoning by the Crown, but rather the unfortunate result that the Crown's strategic trial decisions did not conclude in their favour. The private prosecutor here had the unfair advantage of learning from the public prosecution. This case also raises concerns about Rangitonga's right to be free from double jeopardy. While Rangitonga may not have been at peril of being charged for the wounding, he had grounds for believing he would not face further prosecution for the incident. Under this perspective, Rangitonga $v$ Parker creates a concerning precedent for the use of private prosecutions. However, given the unique circumstances of this case and the court's wide discretion to remove private prosecutions for abuse of process, the author is hopeful that it is unlikely private prosecutions will be permitted to be used in this manner again.

\section{Impartiality and Neutrality}

Private prosecutors are often criticised for lacking the neutrality and impartiality of a public prosecutor. Private prosecutors may choose to instigate proceedings, not as a consequence of state inertia or bias, but rather for their own purpose and benefits, both consciously and subconsciously.

The "Philips principle" advocates for the separation of investigation and prosecution roles. This helps ensure that prosecutorial decisions are decided independently and free from prejudice and improper motives. ${ }^{143}$ As Sir Cyril Philip expressed: ${ }^{144}$

A police officer who carries out an investigation, inevitably and properly, forms a view as to the guilt of the suspect. Having done so, without any kind of improper motive, [that officer] may be inclined to shut his [or her] mind to other evidence telling against the guilt of the suspect or to overestimate the strength of the evidence ... assembled.

143 Law Commission, above n 2, at [325].

144 Cyril Philips Royal Commission on Criminal Procedure (Cmnd 8092, 1981) at 83. 
However, private prosecutors are not required to separate the investigation and prosecution roles. On some occasions, they may play many or most of the roles involved in the process, including investigator, case-manager, witness and advocate. ${ }^{145}$

Further, personal motives may make it hard for a private prosecutor to behave as neutrally as a public prosecutor would. ${ }^{146}$ Almost by definition, private prosecutors have a personal interest in the outcome of the case. ${ }^{147}$ Private prosecutors remain, to the dismay of some practitioners, ${ }^{148}$ not bound to adhere to the Solicitor-General's Prosecution Guidelines (Guidelines), only expected to do so. ${ }^{149}$ These Guidelines require prosecutions to be commenced only where there is sufficient evidence to provide a reasonable prospect of conviction and the prosecution is required in the public interest. ${ }^{150}$

Private prosecutors may also be financially motivated. Judges may impose a sentence of reparation if the offence(s) caused a person to suffer loss of or damage to property, emotional harm, or loss or damage consequential on any emotional or physical harm. The already limited availability of this reparation, however, is further subject to several restrictions. ${ }^{151}$

Further, media reports show some private prosecutors routinely instigate proceedings as part of their self-assumed role of "New Zealand's private prosecutor". ${ }^{152}$ Such "serial litigants" regularly initiate private prosecutions on behalf of others or for the "social justice" of the community as a business, despite lacking formal legal education or being professionally admitted to deliver legal services. ${ }^{153}$ For example, in New Zealand Private Prosecution Service Ltd, the Court held the

145 Richard Buxton "The private prosecutor as a minister of justice" [2009] Crim LR 427 at 429; and Hannah Laming and Annabel Kerley "Private prosecutions: A question of ethics" The Law Society Gazette (online ed, United Kingdom, 23 October 2017).

146 Buxton, above n 145, at 427.

147 At 427

148 Working group representing the Independent Criminal Bar at Hamilton "Submission to the Justice and Electoral Select Committee on the Criminal Procedure (Reform and Modernisation) Bill" at 6-7.

149 Solicitor-General's Prosecution Guidelines, above n 24, at [2.5].

150 See the "Evidential Test" and "Public Interest Test" in Solicitor-General's Prosecution Guidelines, above n 24 , at 6-10.

151 See Sentencing Act 2002, ss 32(3), (5) and 35.

152 "McCready sets sights on PM over Banks case" New Zealand Herald (online ed, Auckland, 17 June 2014).

153 See discussion on New Zealand Private Prosecutions Limited in Law Commission, above n 3, at [261] and the following example news articles: Leith Huffadine "Serial litigant threatens to prosecute Meka Whaitiri if police don't" Stuff (online ed, Wellington, 1 September 2018); Henry Cooke "Private prosecution of Todd Barclay and Bill English suggested" Stuff (online ed, Wellington, 26 June 2017); and Hamish Rutherford "Private prosecution seeks emails' disclosure" Waikato Times (Waikato, 25 June 2013). 
prosecution had been commenced purely with the intention of promoting the interests of the private prosecutor. $^{154}$

Some commentators have argued that impartiality and proper behaviour can be guaranteed ensured by the instruction of private counsel. ${ }^{155}$ This is true to an extent. Counsel are bound by the Guidelines. ${ }^{156}$ Indeed, the Ministry of Justice in their departmental report on the Criminal Procedure (Reform and Modernisation) Bill did not recommend binding private prosecutors to the Guidelines in part because they are already bound when represented by counsel. ${ }^{157}$

However, concerns have also been raised overseas where counsels are able to act as both prosecutors and private practitioners. ${ }^{158}$ There is an inherent tension in this duality. The practitioner is obliged to act in their clients' interests, while simultaneously acting for the public in ensuring the criminal law operates fairly and justly as a minister of justice. Such obligations will not always marry. ${ }^{159}$ For example, in the United Kingdom private prosecutions are increasingly being advocated as a strategy to protect corporate brands from intellectual property offences. ${ }^{160}$ Due to economic factors, few fraud cases are actually prosecuted by the police. ${ }^{161}$ Consequently, "the era of the corporate Private Prosecution is firmly established" and "an all-encompassing brand protection strategy is required in many industries". ${ }^{62}$ Commercial law firms advocate for their clients to commence private prosecutions as it protects brands in a more timely and cost-effective manner than the civil system and sends a strong message of deterrence. ${ }^{163}$ The factors influencing decisions to prosecute in these cases are evidently very different from those that determine public prosecutions.

154 New Zealand Private Prosecution Service Ltd, above 125, at [105].

155 Buxton, above n 145, at 428. See also Tamlyn Edmonds "Private prosecutions: a valuable safeguard" The Law Society Gazette (online ed, United Kingdom, 19 October 2015).

156 Solicitor-General's Prosecution Guidelines, above n 24, at [2.5].

157 Crime Prevention and Criminal Justice Unit, Ministry of Justice and the New Zealand Law Commission Departmental Report for the Justice and Electoral Committee: Criminal Procedure (Reform and Modernisation) Bill (16 May 2011) at 88-89

158 Roger A Fairfax Jr "Delegation of the Criminal Prosecution Function to Private Actors" (2009) 43 UC Davis L Rev 411 at 436.

159 Laming and Kerley, above n 145.

160 R (Virgin Media Ltd) v Zinga [2014] 1 WLR 2228 (Crim App) at [57]. See for example Matt Bosworth "Time to adopt a private prosecution policy?" New Law Journal (online ed, United Kingdom, 20 April 2018).

161 See Lewis and others "Evaluating the Case for Greater Use of Private Prosecutions in England and Wales for fraud offences" (2014) 42(1) IJLCJ 3; and William Boyce and Rachna Gokani "Private Prosecutions" The Law Society Gazette (online ed, United Kingdom, 15 September 2014).

162 Bosworth, above n 160, at 14 .

163 At $14-15$ 
Further, allowing private practitioners to commence prosecutions for their own commercial benefit inevitably brings economic considerations into prosecutorial decisions. Private firms may be tempted to commence unjustified prosecutions to maintain high conviction rates for commercial reasons or to influence matters in their private practice, such as hinting at a prosecution against a civil litigation opponent to encourage settlement. ${ }^{164}$ Commercial pressures may also discourage compliance with disclosure and ethical obligations. The risk of being improperly motivated is especially high where companies are dependent on prosecutions for their revenue. In the United Kingdom, some companies have delegated prosecutorial functions to specialist companies who prosecute for profit. ${ }^{165}$ Similarly, in New Zealand, there has even been a dedicated private prosecution company formed. ${ }^{166}$

While s 26 brings greater judicial oversight to private prosecutions, it does not equip courts with a general ability to ensure that private prosecutions are only being used as a safeguard. The thresholds for the Guidelines and s 26 are distinct. The "Evidential Test" in the Guidelines is met where there is a "reasonable prospect of conviction". ${ }^{167}$ By contrast, charging documents may only be dismissed where evidence is insufficient to prove the elements of the charge, where there is no useful purpose or only nominal punishment would be granted. ${ }^{168}$ Similarly, the "Public Interest Test" is met where "prosecution is required in the public interest". ${ }^{169}$ By contrast, judges can dismiss charging documents only where the proposed prosecution amounts to an abuse of process. ${ }^{170}$ In the United Kingdom there is a greater ability to remove concerning private prosecutions. While courts only disturb decisions of independent prosecutors in "highly exceptional cases", ${ }^{171}$ the Director of Public Prosecutions is able to intervene where they see fit. ${ }^{172}$ The Crown Prosecution Service is able to intervene and discontinue prosecutions where the Code for Crown Prosecutors, ${ }^{173}$ the Guidelines equivalent, is not met. ${ }^{174}$

164 Fairfax Jr, above n 158, at 439-440; and Spencer "Professional private prosecutors and trouble on the trains", above n 111, at 4-6.

165 Spencer "Professional private prosecutors and trouble on the trains", above n 111, at 4-6.

166 Law Commission, above n 3, at [261].

167 Solicitor-General's Prosecution Guidelines, above n 24, at [5.3]-[5.4].

168 See discussion of s 26(3)(a) in Part III(B) above.

169 Solicitor-General's Prosecution Guidelines, above n 24, at [5.5]-[5.11].

170 See discussion of s 26(3)(b) in Part III(B) above.

$171 R$ (on the application of Corner House Research) v Director of the Serious Fraud Office [2008] UKHL 60, [2009] 1 AC 756 at [30].

172 Prosecution of Offences Act 1985, ss 3 and 6(2).

173 CPS The Code for Crown Prosecutors (October 2018) at [4.1]-[4.14].

174 See discussion in $R$ (on the application of Gujra) v Crown Prosecution Service [2011] EWHC 472 (Admin). 
The consequence of these disparities is that private prosecutions may be commenced even where the state would not have instigated them had it behaved free from inertia, bias or incompetence. This makes the decision-making processes surrounding prosecutions inconsistent and allows financially motivated prosecutions to occur. Commercial biases will not always amount to abuse of process. For the purposes of fairness, there should not be arbitrary differences in how people are treated by the criminal law. As the Law Commission rightly stated: ${ }^{175}$

... the making of prosecution decisions is not an area where the economic principle of competition should

predominate. Public interest factors rather than cost ought to be paramount; there is a need for consistency

of decision-making.

Private prosecutions should only be instigated for reasons that match their intended purposes. Normalising and commercialising private prosecutions undermines many of the reasons why prosecution became a state function in the first place. Concerns have been raised in England as to the increased frequency and reliance on private prosecutions as a consequence of economic retrenchment by the state. ${ }^{176}$ One firm alone reported in 2014 it was handling 75 private prosecutions. ${ }^{177}$ By contrast, in Scotland, only one private prosecution has been brought in the last century. ${ }^{178}$ Some endorse this narrow application, ${ }^{179}$ whilst others have advocated for greater ability in Scotland to bring private prosecutions. ${ }^{180} \mathrm{~A}$ balance between these two approaches evidently must be met.

\section{An Effective Safeguard?}

This article has emphasised the important role private prosecutions play as a safeguard against the misuse of state power. However, for private prosecutions to effectively fulfil this role, aggrieved citizens must have the practical ability to commence these proceedings. Currently, costs, investigative burdens and a lack of public awareness seriously limit citizens' ability to commence private prosecutions in their time of need.

175 Law Commission, above n 2, at [334].

176 Paul Peachey "Two-tier justice: Private Prosecution revolution" The Independent (online ed, United Kingdom, 16 August 2014).

177 Peachey, above n 176

178 Findlay Stark "The demise of the private prosecution?" (2013) 72 CLJ 7 at 10

179 At $10-11$.

180 See Scottish Government Justice Committee Petition PE 1633: Private Criminal Prosecution in Scotland (23 February 2018). 


\section{E Investigative Abilities}

Private prosecutors are expected to investigate and manage their own cases. ${ }^{181}$ Despite this, private prosecutors and, where employed, private investigators do not have the same investigative powers and abilities as the state even though such powers will often be crucial in obtaining sufficient evidence. In special cases, some private prosecutors do enjoy powers. For example, The Royal New Zealand Society for the Prevention of Cruelty to Animals (SPCA) inspectors have special powers, such as inspection without a warrant, ${ }^{182}$ and appointed inspectors under HSWA enjoy powers of entry and inspection among others. ${ }^{183}$ However, this is not the case for most private prosecutors.

In some situations, private prosecutors may have the benefit of an investigation already being concluded by a public body. While there is no general duty of disclosure of investigative findings, private prosecutors may be able to gain evidence through the Official Information Act 1982 or Privacy Act $1993 .{ }^{184}$ However, disclosures under these Acts are subject to numerous restrictions. Further, decisions to commence a private prosecution tends to follow, or in the case of HSWA must follow, a decision not to publicly prosecute. This waiting period often means that scene evidence is no longer available by the time a decision to privately prosecute is made. Consequently, in some cases private prosecutors are almost completely reliant on disclosures by enforcement bodies. Scene and other evidence may no longer be available by the time the private prosecutor begins their investigation.

Not having investigative powers or the information of enforcement bodies significantly limits the ability of the private prosecutors to prepare their case. Worthwhile cases may be unable to be prosecuted not for want of evidence, but for the inability to access and find such evidence. Due to the principle of double jeopardy, it is crucial that all prosecutions, whether public or private, are brought in their strongest possible form. Evidently, simple solutions such as expanding powers and capabilities to obtain evidence are not valid. Investigative powers are constrained to certain roles and processes for good reason. Greater information sharing and further granting of investigative powers to relevant unions and reputable organisations could be a step in the right direction. Ultimately however, the potential for stronger relationships between public and private prosecutors is dependent upon the frequency of private prosecutions. As John Macaulay reflected on his involvement in the successful Scottish private prosecution, Sweeney $v X^{185}$

181 As emphasised in Butcher $v$ Auckland District Court [2017] NZHC 2338 at [15].

182 See Animal Welfare Act 1999.

183 HSWA, s 163.

184 Tim Mackenzie "Legal viewpoint - Going private" Safeguard Magazine (online ed, New Zealand, 2016).

185 John Macaulay "Private Prosecution: the Glasgow Rape Case revisited" The Journal of the Law Society of Scotland (online ed, United Kingdom, 16 January 2017) regarding the case Sweeney $v$ X 1982 JC 70 (HCJT). 
It is important to state that we received complete cooperation from the Crown [and the Justiciary Office] at every stage ... after all, private prosecutions did not come along every day of the week.

\section{F Costs}

The most serious obstacle to private prosecutions operating as an effective safeguard is the financial burden of bringing such proceedings. The costs of commencing private prosecution lie with the prosecuting party. In addition, private prosecutions may also need to hire legal representation to help navigate the law or to conduct jury trials, ${ }^{186}$ or hire a private investigator. Further, both successful and unsuccessful private prosecutors risk having to pay all or part of the defendant's costs. ${ }^{187}$ The Costs in Criminal Case Act 1967 gives judges discretion to grant defendant's costs where "just and reasonable". ${ }^{188}$ In doing so, the court must have regard to such factors as whether the prosecution was brought in good faith, whether there was sufficient evidence, investigation and prosecution behaviour and whether or not the defendant was found to be guilty. ${ }^{189}$ Legal aid is not available to private prosecutors as they have not been charged with or convicted of an offence. ${ }^{190}$

The financial burden faced by applicants dramatically diminishes the ability of private prosecutions to operate as an effective safeguard. Costs place private prosecutions "beyond the reach of most concerned citizens" 191 and create a "two-tier system of justice". ${ }^{192}$ Consequently, victims and other aggrieved citizens are often reliant on public generosity to support their case. They may be forced to self-represent or reliant on pro-bono advice or support from legal charities. ${ }^{193}$ Such charitable support may be unsustainable or may only be accessible for certain types of cases. Further, areas of the law where private prosecutions could have a substantial impact due to official reluctance to investigate, such as human trafficking, may be unable to benefit from this safeguard as the expense is beyond the financial capabilities of concerned non-governmental organisations and individuals. ${ }^{194}$

186 CPA, s 10(3).

187 Costs in Criminal Cases Act 1967, s 7(1)(b).

188 Section 5.

189 Section 5(2).

190 Legal Services Act 2011, s 8(1)(a).

191 Osborne, above n 57, at [37].

192 Term taken from Peachey, above n 176.

193 See for example Trainor's appeal in Rangitonga: Wall, above n 46; and the private prosecution of Eramiha Pairama's death in New Zealand Council of Trade Unions "CTU wins second forestry private prosecution" (press release, 12 August 2015).

194 See for example Thomas Harré "Is there a problem in New Zealand waters? Human trafficking prosecution" [2015] NZLJ 382. 
Even where the potential prosecution party may possess the financial capabilities to commence a worthy private prosecution, costs remain a significant deterrent from doing so. Victims and other aggrieved citizens are ultimately forced to answer the uncomfortable question of the price they are willing to pay for their own justice. As Fraser stated in discussing costs for private prosecutions under HSWA, it is: ${ }^{195}$

... difficult to understand why someone would engage in a private prosecution, with all the expense, both emotional and financial, when all access to financial compensation via the courts is barred.

This issue of costs is also concerning when private prosecutions are heavily relied on by the state. For example, the SPCA is largely responsible for the investigation and prosecution of offences under the Animal Welfare Act $1999 .{ }^{196}$ While the most serious cases are handed to the police, the SPCA still commences many important prosecutions. For example, in 2016 the charity brought 47 animal welfare prosecutions. ${ }^{197}$ Having a private charity charged with the enforcement of a criminal statute at its own cost and discretion raises concerns. Insufficient funds and resources mean that many potential prosecutions are not commenced, or where they are, these prosecutions are reliant on public generosity and pro bono support. ${ }^{198}$

Ensuring equal access to private prosecutions may not be easy to solve - indeed the issue is unique to private prosecutions at all. Concerns have continuously been raised as to equitable access for the entire justice sector. ${ }^{199}$ In any event, as Boyce and Gokani rightly argue, this concern of "justice for sale", while in need of address, should not be a reason to abolish the right to private prosecutions entirely, for: ${ }^{200}$

...if "economic retrenchment" is inevitable, should not private prosecutions be seen as an essential safeguard - an opportunity for some victims of criminal conduct to seek justice even when the state has neither the current political will nor the resources to do so for them?

195 Fraser, above n 29, at 1266

196 Animal Welfare Act 1999, ss 121-124.

197 SPCA Annual Report 2016 at 8.

198 See for example "SPCA appeals for cash to fund animal cruelty prosecutions" Stuff (online ed, Wellington, 31 July 2009); and "Top lawyers to work for SPCA for free" New Zealand Herald (online ed, Auckland, 9 April 2009). For more information on specific concerns regarding SPCA prosecutions, see Danielle Rebecca Duffield "Instant Fines for Animal Abuse? The Enforcement of Animal Welfare Offences and the Viability of an Infringement Regime as a Strategy for Reform" (LLB (Hons) Dissertation, University of Otago, 2012).

199 See for example concerns raised in Helen Winkelmann, Chief High Court Judge "Access to Justice - Who Needs Lawyers?" (Ethel Benjamin Address, 7 November 2014).

200 Boyce and Gokani, above n 161. 


\section{G Knowledge of the Safeguard}

Finally, it must be added that for private prosecutions to act as an effective safeguard, citizens must know about this mechanism. While lawyers can inform people, not all potential prosecutors will be able to afford legal advice nor may they think to engage with lawyers without knowing such a possibility exists. Case law shows private prosecutors missing limitation periods in part due to their "understandable" ignorance of the law. ${ }^{201}$ Public prosecutors currently do not have a duty to inform victims or complaints of their ability to commence proceedings privately following decisions not to prosecute. In contrast, the European Union Directive 2012/29 establishing minimum standards on the rights, support and protection of victims of crime provides that victims should be notified of their right to receive sufficient information to decide whether to review a decision not to prosecute. ${ }^{202}$ Whether victims and aggrieved citizens in New Zealand should similarly be notified of their ability to commence a private prosecution needs to be balanced with the threat of further normalisation and the potential for misuse.

\section{CONCLUSION}

The Law Commission, while acknowledging several issues with this mechanism, concluded that the "important constitutional and theoretical place of private prosecutions within our system warrants their retention." 203 This article does not challenge that view. However, the purposes that justify retaining private prosecutions must be reflected in their use. While recent legislative reforms have made substantial improvements in this area, concerns remain. To be a safeguard, private prosecutions must never be normalised, or even more importantly, commercialised. However, at the same time, private prosecutions need be an available and accessible option for those who require them. While finding a balance between English and Scottish approaches is no easy feat, it is evidently a task worthwhile of further attention.

201 See for example Mc Vicar v Department of Corrections [2012] DCR 479 (DC) at [53].

202 Directive 2012/29, above n 56, art 11(3).

203 Law Commission, above n 3, at [255]. 
